\title{
Analytical Study of Physical \& Mechanical Properties of Foamed Concrete Using ETABS
}

\author{
T.Subramani $^{1^{*}}$, R.Amul ${ }^{2}$ \\ ${ }^{1^{*}}$ Managing Director, Priyanka Associates (Civil Engineers and Valuers), Salem, TamilNadu, India. \\ ${ }^{2}$ Assistant Engineer, Highways, Salem, TamilNadu, India. \\ "Corresponding author E-mail: tsmcivil2007@gmail.com
}

\begin{abstract}
Foam concrete is a form of aerated lightweight concrete. Foamed concrete has emerged as most industrial fabric in Production Company. Foam concrete is produced while pre-fashioned foam is brought to slurry, the characteristic of froth is to create an air voids in cementprimarily based absolutely slurry. Foam is generated one by one via using foam generator; the foaming agent is diluted with water and aerated to create the froth. The cement paste or slurry set throughout the foam bubbles and whilst the froth being to degenerate, the paste has enough power to keep its form around the air voids. Consequently, this study investigates bodily and mechanical residences of foamed concrete. Ultimately comparative analyses had been finished to decide the relationships the various numerous mechanical homes parameters of the foamed concrete, especially the compressive strength, flexural electricity, splitting tensile electricity. The specimen analysed by means of the usage of the use of e- tab software program.
\end{abstract}

Keywords: Analytical Study, Physical, Mechanical Properties, Foamed Concrete, ETABSS

\section{Introduction}

The essential packages of foamed concrete encompass structural elements, non-structural walls and thermal insulating materials. Manufacturers evolved foam concretes of various densities to match the above necessities and these merchandise were used in trench reinstatement, bridge abutment; void filling, roof insulation, road sub base, wall production, tunneling and many others.

Foam concrete is a sort of aerated concrete; foam concrete does not comprise coarse combination and may be seemed as an aerated mortar. Foam concrete is produced when pre-shaped foam is added to slurry, the characteristic of foam is to create an air voids in cement-primarily based slurry. Foam is generated one by one by using the use of foam generator; the foaming agent is diluted with water and aerated to create the foam. The cement paste or slurry set around the foam bubbles and when the foam being to degenerate, the paste has sufficient energy to keep its form across the air voids. the foam concrete combination will become too stiff with lower content material, causing bubbles to break, whereas the combos turns into too skinny to preserve the bubbles with excessive water content, main to the separation of bubbles from the combination, water-cement $(w / c)$ ratio generally stages from $0.4-1.25$. Foam concrete may be designed to have any density within the dry density range of three hundred $-1850 \mathrm{~kg} / \mathrm{m} 3$.

\subsection{Making of Foamed Concrete}

The components of foam concrete mix should be set by their functional role in order as follows:

- Foaming agent

- Binding agent
- Water

- Aggregate

Fig. 1 shows the foam concrete.

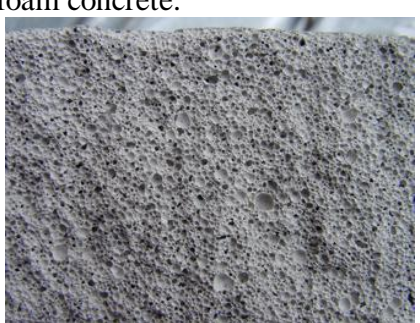

Fig.1: Foam concrete

Foam concrete is a totally fluid, light-weight mobile concrete fill fabric, produced through blending a cement paste (the slurry or mortar), with a one by one synthetic, pre-shaped foam. the density of foam concrete is determined via the ratio of froth to slurry and densities range usually between 300 and $1600 \mathrm{~kg} / \mathrm{m}^{3}$. Sand, pulverized fuel ash (pfa), quarry dirt or limestone dirt can be used to in addition beautify the properties of foam concrete. Foam concrete is produced created through uniform distribution of air bubbles for the duration of the mass of concrete. The foam cells ought to have partitions, which remain solid throughout mixing, transportation, pumping and putting of sparkling concrete. The cells or bubbles are discrete and variety in length between 0.1 and $1 \mathrm{~mm}$. Foam concrete is a loose flowing and may be positioned without compaction.

\section{Methodology}

Fig.2 shows the methodology of the study. 


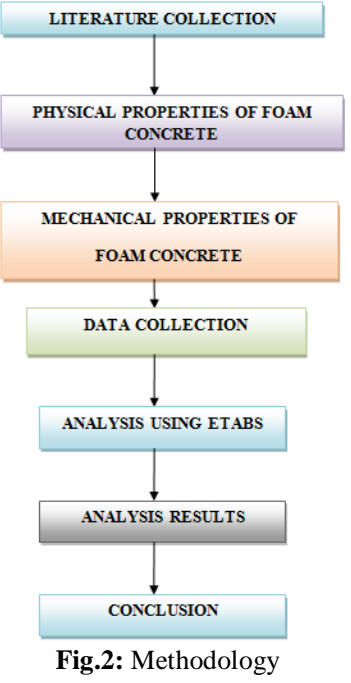

\section{Foam Concrete}

Foam concrete is similar to traditional concrete because it makes use of the same ingredients. But, foam concrete differs from traditional concrete in that using aggregates in the former is removed. A foam aeration agent is used to take in humidity for so long as the product is uncovered to the surroundings, permitting the hydration manner of the cement to progress in its evercontinuing strength development.

The distinction among foam concrete and ordinary concrete is the usage of combination in the foam concrete removed and been replaced with the aid of the homogeneous cells created by air within the shape of small bubble which make use of a solid air cellular structure in preference to subculture aggregates. Compare the unique power (strength-to-density ratio) of foamed concrete with regular weight concrete. Foam concrete mixture with extraordinary substances of the substances is used in this investigation.

- The physical houses (density) as well as a particular structural assets (compressive energy) of foam concrete mixtures have been received first, before the relationship among those houses were decided.

- Foam concrete cubes are organized and the tests are completed in university laboratory.

- $\quad$ Foamed concrete can be located without difficulty, by using pumping if necessary, and does no longer require compaction, vibrating or leveling. It has brilliant resistance to water and frost, and affords a excessive degree of both sound and thermal insulation.

Fig. 3 shows the processing of foam concrete.

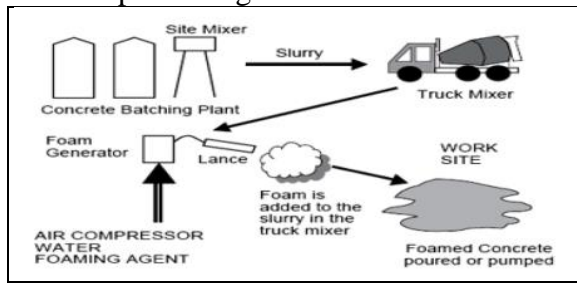

Fig.3: Processing of foam concrete

\subsection{Constituent Materials}

The foamed concrete has been produced by way of using the subsequent elements' viz. cementations cloth (i.e. cement \& fly ash), sand, water and foaming agent. Cementations fabric portland cement is favoured over different cements, including pozzolana. For early stripping and surest mechanical residences, excessivegrade (early electricity) cement is recommended. Thick walls and while using battery-moulds, excess warmth is developing inside and can therefore ask for a lesser grade of cement. The slower, hardening and higher the final great of concrete. Where with in your budget, fly ash may be brought to the mixture to alternative some of the cement. fly ash generally will retard hardening though. on this investigation fifty three grade everyday Portland cement and pleasant fly ash has been used.

\subsection{Sand}

Best residences are completed while deciding on the maximum appropriate raw fabric. The sand is mostly desired from river, that is washed and must be with minimum 20\% fines. Dirt in sand will increase the demand for water and cement, without including to the properties, it also increases shrinkage. A sure, small quantity of fines contributes in the direction of electricity. As in traditional concrete, the sand must be freed from natural material or other impurities. Beaten sand, due to sharp edges may also destroy the foam robotically. On this research, domestically to be had river bed sand has been used.

\subsection{Water}

Whilst water is used to provide foam, it has to be potable and for fine performance, it must not exceed $25^{\circ} \mathrm{c}$. under no circumstances should the foaming agent be introduced in touch with any oil, fat, chemical or different fabric that could harm its feature (oil has a power at the floor-anxiety of water).the oil/wax used in moulds will no longer harm, because the foam by way of then will embedded in mortar. Water to put together the combination has to comply to widespread necessities for concrete.

\subsection{Foam \& Foaming Agent}

Foam is produced by using distribution of fuel in a liquid underneath the impact of a foaming medium, including cleaning soap, oil, acid or a wetting agent. Throughout the manufacturing small bubbles are formed and are separated from liquid through a membrane. Virtually, there are many unique styles of foams with various programs. Consequently, there are many exceptional industries, which use foam-like merchandise.

\section{Properties of Foam Concrete}

\subsection{Physical Properties of Foamed Concrete}

Density, Workability, dry shrinkage, and carbonization has find out with laboratory and utilized.

\subsection{Mechanical Properties of Foam Concrete}

Mechanical residences of the foamed concrete has anticipated via using various constraints primarily based on compressive electricity, dry density, mix share split tensile power, water absorption and so on. compressive electricity of foamed concrete stimulated via many element which include density, age, curing method, aspect and mix proportion. This suggests that coarse sand reasons clustering of bubbles to form abnormal huge pores. For that reason it is able to be concluded that great sand effects in uniform distribution of bubbles and therefore effects in better energy than coarse sand at a given density.

\subsubsection{Mix Proportion and Casting of Specimens}

1. Cement + Fly Ash + Sand

2. Cement + ( Fly Ash + Micro Silica + Sio2 Powder $)+$ Sand

3. Cement + Clay + Sand

4. Cement + Rice Husk Ash + Sand

These mixes were casted under these mix ratios as cement: filler: sand. 
1. $1: 1: 1$

2. $1: 0.5: 1.5$

3. $1: 0.5: 2$

4. $1: 0.5: 3$

\section{Foam Concrete Using E Tabs}

Structural design and analysis has executed with the software program ETABS that's complicated, yet easy to use, software advanced particularly for constructing structures. ETABSs also can manage the biggest and maximum complex constructing models, consisting of a wide variety of nonlinear behaviours necessary for overall performance based totally design, making it the tool of preference for structural engineers within the constructing industry.

\section{ETABS Results}

Fig.4 shows the modelling of building in E tabs.

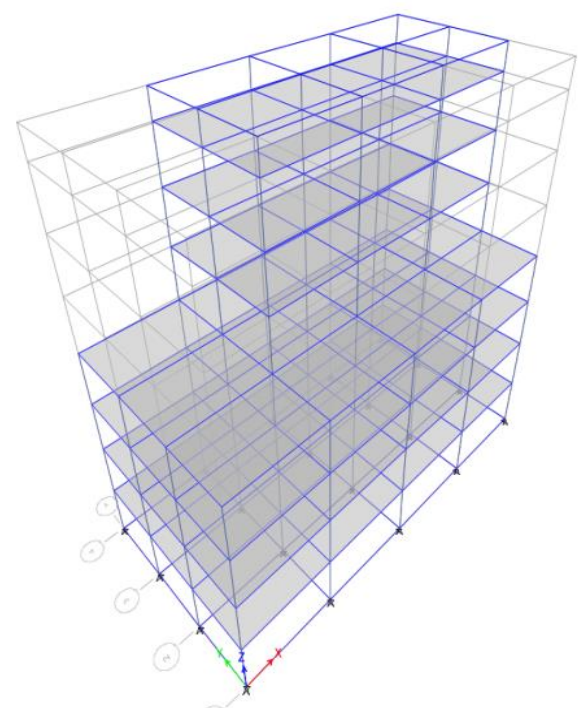

Fig.4: Modelling of building

\subsection{Structure Data}

This area provides model geometry information, including items such as story levels, point coordinates, and element connectivity.

\subsubsection{Storey Data}

Table 1 shows the storey data.

Table 1: Storey data

\begin{tabular}{|c|c|c|c|c|c|}
\hline Name & $\begin{array}{c}\text { Height } \\
\mathrm{mm}\end{array}$ & $\begin{array}{c}\text { Elevation } \\
\mathrm{mm}\end{array}$ & $\begin{array}{c}\text { Master } \\
\text { Story }\end{array}$ & Similar To & $\begin{array}{c}\text { Splice } \\
\text { Story }\end{array}$ \\
\hline Story8 & 1500 & 22500 & Yes & None & No \\
\hline Story7 & 3000 & 21000 & Yes & None & No \\
\hline Story6 & 3000 & 18000 & Yes & None & No \\
\hline Story5 & 3000 & 15000 & Yes & None & No \\
\hline Story4 & 3000 & 12000 & Yes & None & No \\
\hline Story3 & 3000 & 9000 & No & Story4 & No \\
\hline Story2 & 3000 & 6000 & No & Story4 & No \\
\hline Story1 & 3000 & 3000 & No & Story4 & No \\
\hline Base & 0 & 0 & No & None & No \\
\hline
\end{tabular}

\subsubsection{Grid data}

Table 2 shows the grid systems.

\begin{tabular}{|c|c|c|c|c|c|c|}
\hline Name & Type & $\begin{array}{c}\text { Scory } \\
\text { Range }\end{array}$ & $\begin{array}{c}\text { XOrigix } \\
\mathbf{m}\end{array}$ & $\begin{array}{c}\text { YOrigin } \\
\mathbf{m}\end{array}$ & $\begin{array}{c}\text { Kockciou } \\
\text { deg }\end{array}$ & $\begin{array}{c}\text { Bubble Size } \\
\mathbf{m m}\end{array}$ \\
\hline Gl & Cartesian & Dsfáalt & 0 & 0 & 0 & 1250 \\
\hline
\end{tabular}

\subsubsection{Beam Connectivity Data}

Table 3 shows the beam connectivity data.

Table 3: Beam connectivity data

\begin{tabular}{|c|c|c|c|}
\hline Beam & I-End Point & J-End Point & Curve Type \\
\hline B1 & 1 & 2 & None \\
\hline B2 & 2 & 3 & None \\
\hline B3 & 3 & 4 & None \\
\hline B4 & 5 & 6 & None \\
\hline B5 & 6 & 7 & None \\
\hline B6 & 7 & 8 & None \\
\hline B7 & 9 & 10 & None \\
\hline B8 & 10 & 11 & None \\
\hline B9 & 11 & 12 & None \\
\hline B10 & 13 & 14 & None \\
\hline B11 & 14 & 15 & None \\
\hline B12 & 15 & 16 & None \\
\hline B13 & 17 & 18 & None \\
\hline B14 & 18 & 19 & None \\
\hline B15 & 19 & 20 & None \\
\hline B16 & 1 & 5 & None \\
\hline B17 & 5 & 9 & None \\
\hline B18 & 9 & 13 & None \\
\hline B19 & 13 & 17 & None \\
\hline B20 & 2 & 6 & None \\
\hline B21 & 6 & 10 & None \\
\hline B22 & 10 & 14 & None \\
\hline B23 & 14 & 18 & None \\
\hline B24 & 3 & 7 & None \\
\hline B25 & 7 & 11 & None \\
\hline & & & \\
\hline
\end{tabular}

\subsection{Properties}

This area provides property information for materials, frame sections, shell sections, and links.

\subsubsection{Materials}

Table 4 shows the material properties.

Table 4: Material properties

\begin{tabular}{|c|c|c|c|c|c|}
\hline Name & Type & $\begin{array}{c}\mathrm{E} \\
\text { MPa }\end{array}$ & $\mathrm{v}$ & $\begin{array}{c}\text { Unit Weight } \\
\mathrm{kN} / \mathrm{m}^{3}\end{array}$ & Design Strengths \\
\hline A615Gr60 & Rebar & 199947.98 & 0.3 & 76.9729 & $\begin{array}{c}\mathrm{FX}=413.69 \mathrm{MPa}, \\
\mathrm{Fu}=620.53 \mathrm{MPa}\end{array}$ \\
\hline A992Fy50 & Steel & 199947.98 & 0.3 & 76.9729 & $\begin{array}{c}\mathrm{F}=\mathbf{3 4 4 . 7 4} \mathrm{MPa}, \\
\mathrm{Fu}=448.16 \mathrm{MPa}\end{array}$ \\
\hline M30 & Concrete & $\mathbf{2 7 3 8 6 . 1 3}$ & 0.3 & 13.7293 & $\mathrm{Fc}=30 \mathrm{MPa}$ \\
\hline M30-1 & Concrete & $\mathbf{2 7 3 8 6 . 1 3}$ & 0.3 & 13.7293 & $\mathrm{Fc}=30 \mathrm{MPa}$ \\
\hline
\end{tabular}

\subsubsection{Frame Sections}

Table 5 shows the frame sections summary.

Table 5: Frame sections - summary
\begin{tabular}{|c|c|c|}
\hline Name & Material & Shape \\
\hline A-Lat Bm & A992Fy50 & Auto Select \\
\hline column & M30-1 & Concrete Rectangular \\
\hline ISLB600 & A992Fy50 & Steel I/Wide Flange \\
\hline
\end{tabular}

\subsubsection{Shell Sections}

Table 6 shows the shell sections.

$$
\begin{array}{lcccc} 
& \multicolumn{3}{c}{\text { Table 6: Shell sections }} \\
\text { Name } & \text { Design Type } & \text { Element Type } & \text { Material } & \text { Total Thickness mm } \\
\text { Slab2 } & \text { Slab } & \text { Shell-Thin } & \text { M30 } & 200
\end{array}
$$

\subsubsection{Reinforcement Sizes}

Table 6 shows the reinforcing bar sizes.

Table 7: Reinforcing Bar Sizes 


\begin{tabular}{|c|c|c|}
\hline Name & $\begin{array}{c}\text { Diameter } \\
\mathbf{m m}\end{array}$ & $\begin{array}{c}\text { Area } \\
\mathbf{m m}^{\mathbf{2}}\end{array}$ \\
\hline 10 & 10 & 79 \\
\hline 20 & 20 & 314 \\
\hline
\end{tabular}

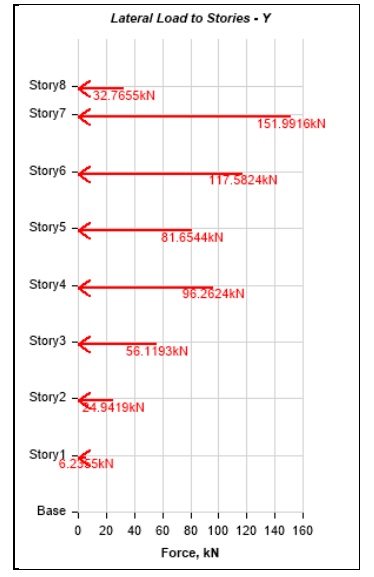

Fig.6: Lateral load in Y - direction

\subsection{Loads}

This area provides loading information as applied to the model.

\subsubsection{Load Patterns}

Table 8 shows the load patterns.

Table 8: Load Patterns

\begin{tabular}{|c|c|c|c|}
\hline Name & Type & $\begin{array}{c}\text { Self Weight } \\
\text { Multiplier }\end{array}$ & Auto Load \\
\hline Dead & Dead & 1 & \\
\hline Live & Live & 0 & \\
\hline sei & Seismic & 0 & IS1893 2002 \\
\hline wi & Wind & 0 & Indian IS875:1987 \\
\hline
\end{tabular}

\subsubsection{Calculated Base Shear}

Table 9 shows the calculated base shear.

Table 9: Calculated base shear

\begin{tabular}{|c|c|c|c|}
\hline Direction & $\begin{array}{c}\text { Period Used } \\
(\mathrm{sec})\end{array}$ & $\begin{array}{c}\mathrm{W} \\
(\mathrm{kN})\end{array}$ & $\begin{array}{c}\mathrm{V}_{\mathrm{b}} \\
(\mathrm{kN})\end{array}$ \\
\hline $\mathrm{X}$ & 0.426 & 6306.1445 & $\mathbf{5 6 7 . 5 5 3}$ \\
\hline $\mathrm{Y}$ & 0.477 & 6306.1445 & $\mathbf{5 6 7 . 5 5 3}$ \\
\hline $\mathrm{X}$ + Ecc. Y & 0.426 & 6306.1445 & 567.553 \\
\hline Y + Ecc. X & 0.477 & 6306.1445 & 567.553 \\
\hline X - Ecc. Y & 0.426 & 6306.1445 & 567.553 \\
\hline Y - Ecc. X & 0.477 & 6306.1445 & 567.553 \\
\hline
\end{tabular}

Fig. 5 shows the Lateral load in $\mathrm{x}-$ direction

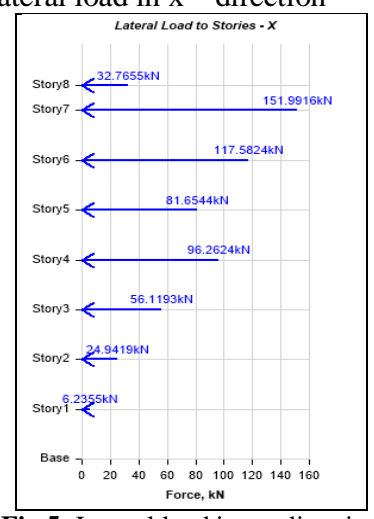

Fig.5: Lateral load in $\mathrm{x}$ - direction

Table 10 shows the Lateral load in $\mathrm{x}$ - direction

Table 10: Lateral load in $\mathrm{x}$ - direction

\begin{tabular}{|c|c|c|c|}
\hline Story & Elevation & X-Dir & Y-Dir \\
\hline & $\mathrm{m}$ & $\mathrm{kN}$ & $\mathrm{kN}$ \\
\hline Story8 & 22.5 & 32.7655 & 0 \\
\hline Story7 & 21 & 151.9916 & 0 \\
\hline Story6 & 18 & 117.5824 & 0 \\
\hline Story5 & 15 & 81.6544 & 0 \\
\hline Story4 & 12 & 96.2624 & 0 \\
\hline Story3 & 9 & 56.1193 & 0 \\
\hline Story2 & 6 & 24.9419 & 0 \\
\hline Storyl & 3 & 6.2355 & 0 \\
\hline Base & 0 & 0 & 0 \\
\hline
\end{tabular}

Fig.6 shows the Lateral load in $\mathrm{Y}$ - direction

\begin{tabular}{|c|c|c|c|}
\hline Story & Elevation & X-Dir & Y-Dir \\
\hline & $\mathbf{m}$ & $\mathrm{kN}$ & $\mathrm{kN}$ \\
\hline Story8 & 22.5 & 0 & 32.7655 \\
\hline Story7 & 21 & 0 & 151.9916 \\
\hline Story6 & 18 & 0 & 117.5824 \\
\hline Story5 & 15 & 0 & 81.6544 \\
\hline Story 4 & 12 & 0 & 96.2624 \\
\hline Story3 & 9 & 0 & 56.1193 \\
\hline Story2 & 6 & 0 & 24.9419 \\
\hline Storyl & 3 & 0 & 6.2355 \\
\hline Base & 0 & 0 & 0 \\
\hline
\end{tabular}

Fig. 7 shows the rendering view for structure.

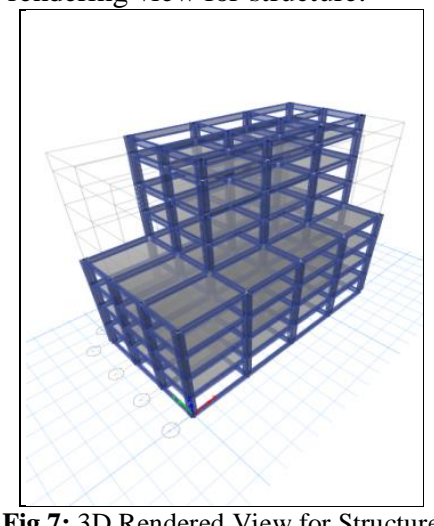

Fig.7: 3D Rendered View for Structure

Fig. 8 shows the slab assignment.

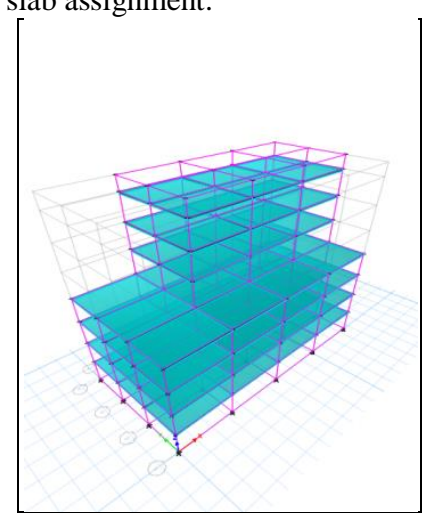

Fig.8: Slab assignment

\section{Conclusion}

From the study we conclude that foam concrete is weight less with strength while compare with conventional concrete when it was highly porous. The result has been achieved through the analysis 
and designs the foam concrete in ETABS software and mechanical tests.

\section{References}

[1]. T.Subramani, J.Jayalakshmi , " Analytical Investigation Of Bonded Glass Fibre Reinforced Polymer Sheets With Reinforced Concrete Beam Using Ansys", International Journal of Application or Innovation in Engineering \& Management (IJAIEM) , Volume 4, Issue 5, pp. 105-112, 2015

[2]. T.Subramani. , S.Vishnupriya, "Finite Element Analysis of a Natural Fiber (Maize) Composite Beam", International Journal of Modern Engineering Research, Volume. 4, Issue. 6 (Version 1), pp $1-7,2014$,

[3]. T.Subramani., R.Senthil Kumar, "Modelling and Analysis of Hybrid Composite Joint Using Fem in ANSYS", International Journal of Modern Engineering Research, Volume 4, Issue 6 (Version 1), pp 41- 46, 2014

[4]. T.Subramani, S.Sharmila, "Prediction of Deflection and Stresses of Laminated Composite Plate with Artificial Neural Network Aid", International Journal of Modern Engineering Research, Volume 4, Issue 6(Version 1), pp $51-58,2014$

[5]. T.Subramani., S.Sundar, M.Senthilkumar, "Investigation of the Behaviour for Reinforced Concrete Beam Using Non Linear Three Dimensional Finite Elements", International Journal of Modern Engineering Research, Volume. 4, Issue. 6 (Version 2), pp 13 -18, 2014 ,

[6]. T.Subramani, A.Arul, "Design And Analysis Of Hybrid Composite Lap Joint Using Fem" International Journal of Engineering Research and Applications, Volume. 4, Issue. 6 (Version 5), pp 289- 295, 2014.

[7]. T.Subramani., J.Jothi,, M.Kavitha "Earthquake Analysis Of Structure By Base Isolation Technique In SAP", International Journal of Engineering Research and Applications, Volume. 4, Issue. 6 (Version 5), pp 296 - 305, 2014.

[8]. T.Subramani., R.Manivannan.R, M.Kavitha, "Crack Identification In Reinforced Concrete Beams Using Ansys Software" ,International Journal of Engineering Research and Applications, Volume. 4, Issue. 6 (Version 6), pp 133 - 141, 2014.

[9]. T.Subramani., Reni Kuruvilla, J.Jayalakshmi., "Nonlinear Analysis Of Reinforced Concrete Column With Fiber Reinforced Polymer Bars" International Journal of Engineering Research and Applications Volume. 4, Issue. 6 (Version 5), pp 306- 316, 2014.

[10]. T.Subramani, D.Sakthi Kumar, S.Badrinarayanan. "Fem Modelling And Analysis Of Reinforced Concrete Section With Light Weight Blocks Infill " International Journal of Engineering Research and Applications, Volume. 4, Issue. 6 (Version 6), pp 142 - 149, 2014

[11]. T.Subramani, B.Saravanan., J.Jayalakshmi., "Dynamic Analysis Of Flanged Shear Wall Using Staad Pro", International Journal of Engineering Research and Applications, Volume. 4, Issue. 6 (Version 6), pp 150 - 155, 2014.

[12]. T.Subramani, M.Subramani., K.Prasath.,"Analysis Of Three Dimensional Horizontal Reinforced Concrete Curved Beam Using Ansys" International Journal of Engineering Research and Applications, Volume. 4, Issue. 6 (Version 6), pp 156 - 161, 2014.

[13]. T.Subramani., K.Bharathi Devi., M.S.Saravanan. , Suboth Analysis Of RC Structures Subject To Vibration By Using Ansys,' International Journal of Engineering Research and Applications Vol. 4, Issue 12(Version 5), pp.45-54, 2014.

[14]. T.Subramani., K.Bharathi Devi., M.S.Saravanan., Suboth Thomas, "Analysis Of Seismic Performance Of Rock Block Structures With STAAD Pro International Journal of Engineering Research and Applications Vol. 4, Issue 12(Version 5), pp.55- 68, 2014

[15]. T.Subramani., T.Krishnan., M.S.Saravanan.M , Suboth Thomas, "Finite Element Modeling On Behaviour Of Reinforced Concrete Beam Column Joints Retrofitted With CFRP Sheets Using Ansys" International Journal of Engineering Research and Applications Vol. 4, Issue 12(Version 5), pp.69 -76, 2014

[16]. T.Subramani., S.Krishnan., M.S.Saravanan.M, Suboth Thoma "Analysis Of Retrofitting Non-Linear Finite Element Of RCC Beam And Column Using Ansys" International Journal of Engineering Research and Applications ,Vol. 4, Issue 12(Version 5), pp.77-87, 2014

[17]. T.Subramani, J.Jayalakshmi , " Analytical Investigation Of Bonded Glass Fibre Reinforced Polymer Sheets With Reinforced Concrete Beam Using Ansys" , International Journal of Application or Innovation in Engineering \& Management (IJAIEM), Volume 4, Issue 5, pp. 105-112, 2015
[18]. T.Subramani and M.Kavitha, "Analysis Of Reliability Of Steel Frame Systems With Semi-Rigid Connections Using Numerical Method And Finite Element Analysis", International Journal of Applied Engineering Research (IJAER), Volume 10, Number 38,Special Issues, pp.28240-28246, 2015.

[19]. T.Subramani, M.S.Saravanan, "Analysis Of Non Linear Reinforced And Post Tensioned Concrete Beams Using ANSYS”, International Journal of Applied Engineering Research (IJAER) International Journal of Applied Engineering Research (IJAER), Volume 10 Number 38 Special Issues, pp.28247-28252, 2015

[20]. T.Subramani, K.Balamurugan , " Finite Element Anaylsis Of Composite Element For FRP Reinforced Concrete Slab By Using ANSYS" , International Journal of Application or Innovation in Engineering \& Management (IJAIEM) , Volume 5, Issue 5, pp. 076-084, 2016.

[21]. T.Subramani, V.Kanian Poonkundran , " Prefabricated Multistory Structure Exposure To Engineering Seismicity By Using SAP" , International Journal of Application or Innovation in Engineering \& Management (IJAIEM), Volume 5, Issue 5, pp. 123-131 , 2016.

[22]. T.Subramani, A.Kumaravel , "Analysis Of Polymer Fibre Reinforced Concrete Pavements By Using ANSYS" , International Journal of Application or Innovation in Engineering \& Management (IJAIEM), Volume 5, Issue 5, pp. 132-139, 2016

[23]. T.Subramani, R.Praburaj , " Pushover Anaylsis Of Retrofitted Reinforced Concrete Buildings By Using SAP" , International Journal of Application or Innovation in Engineering \& Management (IJAIEM), Volume 5, Issue 5, pp. 140-147, 2016.

[24]. T.Subramani, M.Senthilkumar , "Finite Element Anaylsis Of RC Beams With Externally Bonded Simcon Laminates By Using ANSYS" , International Journal of Application or Innovation in Engineering \& Management (IJAIEM), Volume 5, Issue 5, pp. $148-155,2016$

[25]. T.Subramani, R.Vasanthi , " Earth Quake Resistant Building Using SAP" , International Journal of Application or Innovation in Engineering \& Management (IJAIEM), Volume 5, Issue 5, pp. $173-181,2016$

[26]. T.Subramani, A.Selvam , "Studies On Economical Configuration Of RCC And Prestressed Shell Roofs By Using ANSYS " International Journal of Application or Innovation in Engineering \& Management (IJAIEM), Volume 5, Issue 5, pp. 182-191, 2016.

[27]. T.Subramani, A.Anbuchezian , "Experimental Investigation On Flexural Behavior Of Folded Ferro Cement Panels " , International Journal of Application or Innovation in Engineering \& Management (IJAIEM), Volume 6, Issue 3, March 2017 , pp. 045 049 , ISSN 2319 - 4847.

[28]. T.Subramani, A. Fizoor Rahman , " An Experimental Study On The Properties Of Pet Fibre Reinforced Concrete " , International Journal of Application or Innovation in Engineering \& Management (IJAIEM), Volume 6, Issue 3, March 2017 , pp. 058 066 , ISSN 2319 - 4847.

[29]. T.Subramani, S.Poongothai, S.Priyanka , " Analytical Study Of T Beam Column Joint Using FEM Software " , International Journal of Emerging Trends \& Technology in Computer Science (IJETTCS), Volume 6, Issue 3, May - June 2017 , pp. 148-156 , ISSN 2278-6856

[30]. T.Subramani, R.Ganapathy,V.Manoharan, M.Balamurugan, R.Murugesan , " Design And Analysis Of Light Weight Concrete Building Using ETAB With Respect To Dynamic Loading ", International Journal of Emerging Trends \& Technology in Computer Science (IJETTCS), Volume 6, Issue 3, May - June 2017 ,pp. 252-258, ISSN 2278-6856.

[31]. T.Subramani, A.Mohammed Ali, R.Karthikeyan, E.Panner Selvan K.Periyasamy , " Analytical Study Of T-Beam Using ANSYS ", International Journal of Emerging Trends \& Technology in Computer Science (IJETTCS), Volume 6, Issue 3, May - June 2017 , pp. 259-266, ISSN 2278-6856.

[32]. T.Subramani, V.Kalaivanan, S.Priyaranjithkumar, P.Sasikumar, P.Vinoth Kumar, " Design And Analysis Of Multistorey Building With Respect To Seismic Loads Using ETABS " , International Journal of Emerging Trends \& Technology in Computer Science (IJETTCS), Volume 6, Issue 3, May - June 2017, pp. 267-274, ISSN 2278-6856. 